Proc. Estonian Acad. Sci. Geol., 2005, 54, 1, 40-51

\title{
Grain size of the bottom sediments of Lake Väike Juusa (southern Estonia) as the indicator of water-level fluctuations
}

\author{
Jaan-Mati Punning, Jaanus Terasmaa, and Ene Kadastik \\ Institute of Ecology at Tallinn Pedagogical University, Kevade 2, 10137 Tallinn, Estonia; \\ mati@eco.edu.ee
}

Received 27 January 2005, in revised form 1 February 2005

\begin{abstract}
Surface sediments and sediment cores from Lake Väike Juusa were studied in order to examine the dependence of the sedimentation regime on the topography and development of the lake. Close relationship was established between the grain size of the surface samples and depth of water at the sampling site. The data obtained show that in the lake the accumulation area is situated deeper than $4.0 \mathrm{~m}$. The grain size data for three sediment cores allowed reconstruction of lake-level fluctuations and their amplitude.
\end{abstract}

Key words: lithology, lake sediments, lake-level fluctuations, palaeolimnology, Estonia.

\section{INTRODUCTION}

An essential issue in palaeolimnology is understanding the key events in the history of lake ecosystems and, on this basis, generating ideas for lake restoration. The state and evolution of lake ecosystems are regulated by several biotic and abiotic factors, natural and man-induced processes of various levels and duration. One of the best ways to obtain long-term data on the development of a lake ecosystem is the palaeolimnological method.

The most complicated problem in applying the palaeolimnological approach is the interpretation of data obtained by sediment studies and their temporal calibration with certain in-lake and catchment events affecting the lake status. Numerous studies are focused on the direct responses of different bioindicators 
(pollen, diatoms, chironomids, macrophytes), geochemical records, hydrological changes in the trophic state of a lake (Dearing 1983; Engstrom et al. 1985; Punning \& Leeben 2003; Marchetto et al. 2004). Less attention has been paid to sedimentology, especially grain size of lake sediments, however, several studies have been successful in investigating water-level variations in small temperate lakes (Digerfeldt 1986; Dearing 1997; Punning et al. 2004a). Fluctuations of lake water level alter the lake morphometry and transform the characteristics of sedimentation zones of the lake bed, thereby directly influencing sedimentation and resuspension. Based on sediment composition and bottom morphometry of the lake, areas with different sedimentation regimes can be distinguished (Håkanson 1977; Håkanson \& Jansson 1983; Blais \& Klaff 1995). These are the erosion, transportation, and accumulation areas. Erosion areas are located most frequently in shallow waters and/or in deep slopes and are characterized by hard or consolidate deposits. Sediments within the transportation areas vary largely from sand to loose mud. Deposits within the accumulation areas are comparatively loose and mainly fine-grained, with high water and organic contents. Changes in water level may change properties of sediments accumulated in the lake, for example, their mineral matter content and grain size distribution, and will lead to increase in the rates of mineral matter delivery (Shteinman \& Parparov 1997). Such a comprehensive lithological approach to the study of lake sediments has been developed in Estonia by A. Raukas (see Raukas 1999).

Within the areas formed in the described way at different sedimentation regimes, the chemical and lithological composition of lake sediments varies according to certain major regularities. The interpretation of all sedimentological data requires knowledge of the principal regularities of sediment accumulation: how the sediment is formed in the lake, which factors have influenced the sedimentation process, the composition of the deposited material and its origin. The amount of mineral matter and grain size composition of sediment are the indicators of processes in the lake basin (Boyle 2001) and changes in water level, which enable reconstruction of the hydrological balance of the lake. Recent studies in palaeolimnology (Beierle et al. 2002) have shown that the quantitative and qualitative analyses can be used to describe sedimentological processes and distinguish the changes in past environment. Our recent analysis revealed that the lake depth, slope inclination, and distance to the shore determine up to half of the variation in the composition of sediments (Terasmaa 2005). Analyses of surface sediments of some small lakes such as Lake Viitna Linajärv (Punning et al. 2004b) showed that the accumulation, redistribution, and composition of sediments are related to bottom topography, and changes in their lithological composition are most probably caused by lake-level fluctuations.

The aim of the present study is to explain in detail the spatiotemporal regularities of the lacustrine sedimentation process in a small lake. Grain size analyses of surface sediment samples and samples from three deep cores of Lake Väike Juusa were performed to determine the relationships in the lithological 
composition, especially between grain size and topography of the sedimentation area. On the basis of these connections we can reconstruct changes in lake water level in the past and their impact on the development of the lake ecosystem, and predict the evolution of lakes in the future in case the environmental conditions change.

\section{STUDY AREA}

Lake Väike Juusa (hereafter L. Juusa) is situated in the southern part of Estonia $\left(58^{\circ} 03^{\prime} \mathrm{N}\right.$ and $\left.26^{\circ} 30^{\prime} \mathrm{E}\right)$ on the Otepää Heights (Fig. 1). The relief of the Otepää Heights varies greatly. The hillocks that border the lake are formed of glaciofluvial deposits and till and have steep slopes. Small depressions between the hillocks were formed after the withdrawal of glaciers from marginal landforms during the Otepää stage about 12 700-12 $200 \mathrm{yr}$ BP (Punning et al. 1968). Many water basins of the region like L. Juusa are of glaciokarstic origin. The water level of the lake is $122 \mathrm{~m}$ a.s.l. The difference between relative heights in the catchment area is nearly $60 \mathrm{~m}$; close to the lake the relative heights are within $20 \mathrm{~m}$. The northeastern and eastern shores are the steepest. The surrounding terrace is ca $2 \mathrm{~m}$ higher than the present water level. The lake is situated in semiopen cultural landscape, with two farms located nearby and a paludified area on its western side. The forests are birch-dominated, but alder and willow are widespread close to the lake.

Lake Juusa is a small 3 ha hardwater lake with a maximum length of $250 \mathrm{~m}$ and width of $160 \mathrm{~m}$. The mean and maximum depths of the lake are 3.7 and $5.8 \mathrm{~m}$, respectively. It is a mesotrophic-eutrophic dimictic lake with strong stratification during spring and summer seasons. In summer the thermocline deepens from about $2.5 \mathrm{~m}$ in June to $3-3.5 \mathrm{~m}$ in July-August. The near-bottom layers contain no oxygen during the whole year. The decrease in temperature in September induces gradual onset of autumnal circulation, and the water column becomes unstratified at the end of October. The lake is covered with ice from December to April. The measured mean values of the water $\mathrm{pH}$ were ca 7.7 at the surface and 6.6 at a depth of $5 \mathrm{~m}$ in the years 2002-2003.

Lake Juusa is characterized by a concave hypsographic curve and very small dynamic ratio $(\mathrm{DR}=0.04)$. The lake bottom has a relatively regular shape; the near-shore zone deepens abruptly. The deep area is large and gently sloping. The slope inclination is greatest (up to 20\%) at depths from 0 to $3 \mathrm{~m}$ (see Fig. 1b). The inclination of the deeper slope decreases rapidly and is only $2 \%$ on average at depths of 5-6 m.

The bottom sediments of L. Juusa are up to $12 \mathrm{~m}$ thick in the deepest part of the lake (Fig. 1c). The upper sediments are brownish gyttja rich in water and organic matter. The content of dry matter increases downwards. The lake sediments are lying on silt and sand. Large variations in organic matter and carbonates in the sediments down the core reflect significant changes in sedimentation conditions 


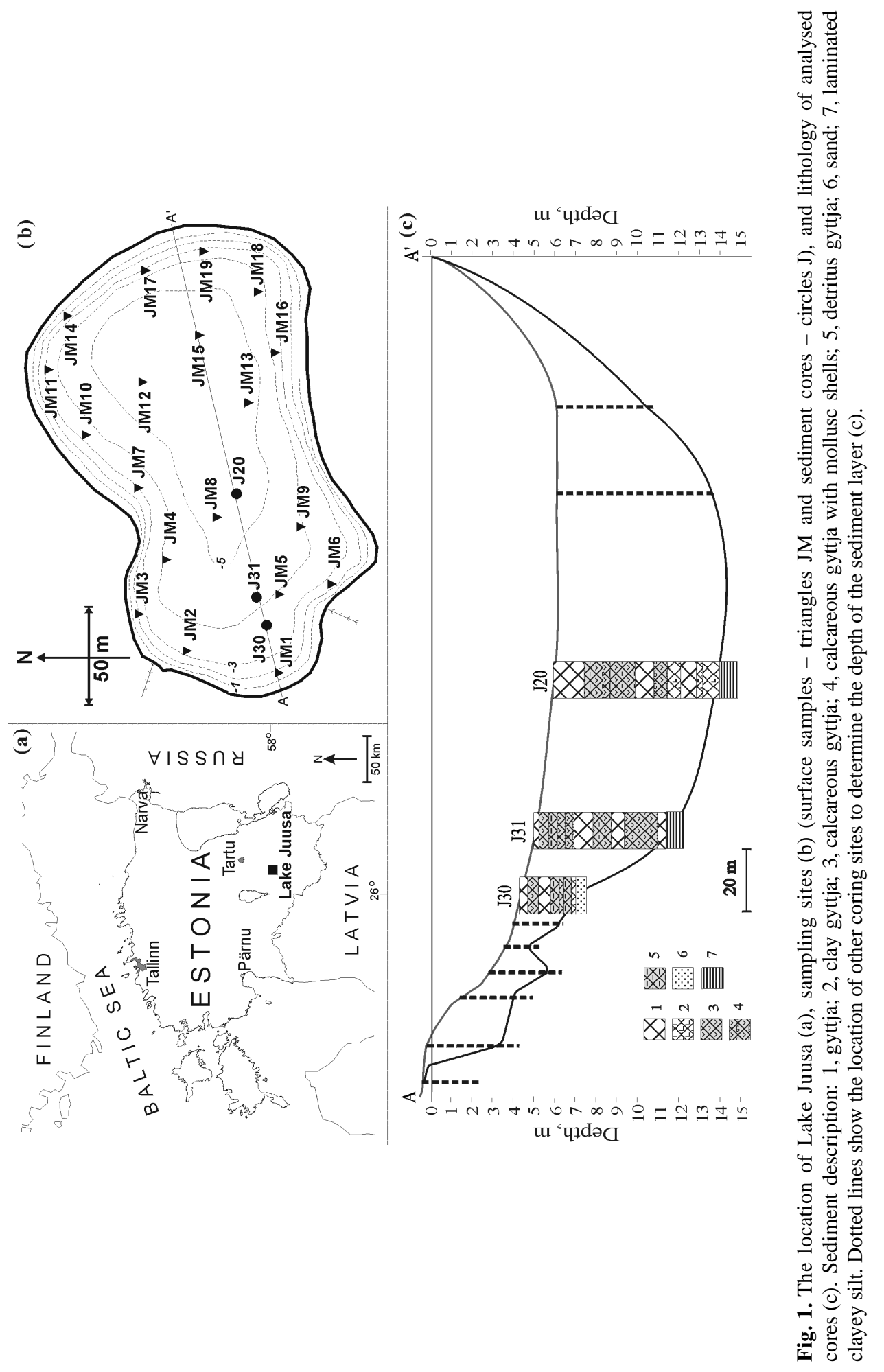


during the Holocene. A comprehensive analysis of sediment cores from L. Juusa considering different lithological, geochemical, and palaeobiological criteria allowed us to reconstruct the history of lake-level fluctuations (Punning et al. 2005).

\section{METHODS}

The surface sediments were sampled with a Livingstone-Vallentyne type piston corer and a gravity corer modified at the Institute of Ecology. A total of 19 samples, each $10 \mathrm{~cm}$ thick, were collected (Fig. 1b) and packed into hermetic plastic boxes. Three sediment cores were taken from the ice during winters of 2001-2003 with a Belarus (Russian) peat sampler (Fig. 1b,c). The cores were lithologically described in the field. The thickness of lake sediments and the basin were topographically mapped. Mapping was carried out from a boat in the icefree period, and from ice in winter by using the echo sounder, measure-disk, and coring-tubes. Water depths and sediment thickness were measured at each coring site. The sediment cores were divided into $50 \mathrm{~cm}$ long pieces, photographed, and wrapped into plastic. The samples were preserved in a refrigerator in darkness. The subsampling for different analysis was performed in the laboratory prior to analysis.

Standard methods were used for processing samples (Bengtsson \& Enell 1986; Boyle 2001). First the wet mass was measured at a fixed volume, then the samples were dried at $105^{\circ} \mathrm{C}$ to constant mass, and the dry mass was calculated. Thereafter the samples were kept for $3.5 \mathrm{~h}$ at $550^{\circ} \mathrm{C}$ in a previously weighed crucible in a muffle furnace. Next the samples were weighed and the loss on ignition (LOI) was determined. Samples for grain size analysis taken from the cores were $2 \mathrm{~cm}$ thick and weighed about 30-60 g.

The grain size composition of sediment samples was determined by wet sieving. The previously frozen samples were melted and soaked in water for about $48 \mathrm{~h}$. The soaked samples were treated with ultrasound for about $30 \mathrm{~min}$ before wet sieving. Wet sieving was carried out on four metallic woven mesh sieves in a Vibratory Sieve Shaker "Analysette 3" PRO. The weighed sediment subsample was placed on the upper sieve and after a proper period of shaking (generally 15-20 min), the content of each sieve was weighed and separated. Particle size was determined from the amount of the sediment that remained on each sieve partitioning of the fractions $>0.315,0.315-0.1,0.1-0.063,0.063-0.036$, and $<0.036 \mathrm{~mm}$ (Folk 1980; Last 2001). As the accumulation zone in the lake is characterized mainly by the content of the fine-grained fraction (Håkanson \& Jansson 1983), we included in our analysis a generalized parameter $F_{36}$, which shows the proportion of the finest fraction $(<0.036 \mathrm{~mm})$ among all the fractions. Cartographic analysis, visualization, and digital elevation models of the lake bottom topography were made with the programs MapInfo Professional 5.5 and VerticalMapper 2.5. 


\section{RESULTS}

The composition of the 19 samples taken from the surface sediment of L. Juusa (Fig. 1b) varied largely due to the slope inclination. The sediments analysed consisted mainly of unconsolidated dark brownish to reddish gyttja with fragments of plant remains and pieces of mollusc shells. The content of dry matter in the sediment was $8-32 \%$, depending on the topography of sampling sites. The spatial distribution of mineral matter and its grain size composition in the surface sediment of L. Juusa revealed the same main tendencies as the dry matter distribution: the highest values were recorded in the near-shore zones in the eastern and northeastern parts of the lake. In the analysed surface samples the proportion of mineral matter was between 50 and 90\% (Terasmaa 2004, 2005).

In Table 1a the percentages of different grain size fractions and the relative proportion $\left(\mathrm{F}_{36}\right)$ of the finest fraction $(<0.036 \mathrm{~mm})$ are presented in the increasing order of the water depth at each sampling site. The samples with the $F_{36}$ value less than 0.9 (in bold) represent mostly the sediments with a finer grain gize.

Three sediment cores were taken along an E-W profile from the deepest area (core J20) towards the shore (cores J31 and J30). The sediments analysed consisted mainly of dark brownish- to greenish-brown gyttja with mineral silt and sand particles and fragments of mollusc shells. The content of dry matter in the sediment was 5.3-71.3\%, depending on the depth of sampling and lithology of lake sediment. The content of mineral matter varied between 24.5 and $94.9 \%$, whereas the highest values were recorded in the samples from lower parts of the cores in deeper zones of the lake. Lake sediments were underlain by silt. In all cores detritus gyttja and carbonaceous gyttja with different $\mathrm{CaCO}_{3}$ contents (from 6 to $50 \%$ ) could be distinguished (Fig. 1c) (according to Troels-Smith 1955; Aaby \& Berglund 1986). The colour of sediments varied from dark to light brown and lighter colour variations disappeared quickly after exposure to air. In some layers mollusc shells and plant remains were present. The lower part of sediments (2-3 m below basal silt) of cores J20 and J31 were compact and consolidated. The lower layer of core J30 contained gravel grains. The 30-50 cm thick surface layers of gyttja were so unconsolidated in all cores that it was necessary to use the Livingstone-Vallentyne sampler. The values of the mineral and organic matter differ, depending on the location of cores. The mineral matter content of lacustrine sediments varies from 30 to $80 \%$ in core J20 (water depth 5.1 m, see Fig. 1b,c), from 35 to $80 \%$ in core J31 (water depth $4.1 \mathrm{~m}$ ), and from 10 to $60 \%$ in core J30 (water depth $3.6 \mathrm{~m}$ ).

A total of 62 samples representing all lithological types of sediments were taken for grain size analysis from deep cores (Fig. 1c). Table 1b,c,d shows the percentages of different grain size fractions and values of $\mathrm{F}_{36}$ for cores J20, J31, and J30. The sampling depths are given from the surface of sediments. The same method of data processing was used in cores with the $F_{36}$ values less than 0.9 to distinguish different intervals. 
Table 1. Percentage contents of different grain size fractions $(\mathrm{mm})$ in the surface samples and sediment core samples from Lake Juusa. Depths for surface samples are given from lake surface and for sediment cores from the sediment surface. $F_{36}$ denotes the ratio of the fraction $<0.036 \mathrm{~mm}$ to the total. Numbers in bold denote samples with $\mathrm{F}_{36}<0.9$

\begin{tabular}{c|r|r|r|r|r|r}
\multicolumn{6}{l}{ (a) Surface samples } \\
$\begin{array}{c}\text { Water } \\
\text { depth, } \\
\text { m }\end{array}$ & $>0.315$ & $\begin{array}{c}0.315- \\
0.1\end{array}$ & $\begin{array}{c}0.1- \\
0.063\end{array}$ & $\begin{array}{l}0.063- \\
0.036\end{array}$ & $<0.036$ & F $_{36}$ \\
\hline $\mathbf{1 . 9}$ & $\mathbf{2 6 . 3}$ & $\mathbf{3 4 . 3}$ & $\mathbf{1 0 . 2}$ & $\mathbf{1 0 . 4}$ & $\mathbf{1 8 . 8}$ & $\mathbf{0 . 2}$ \\
$\mathbf{2 . 1}$ & $\mathbf{2 9 . 6}$ & $\mathbf{2 9 . 2}$ & $\mathbf{9 . 7}$ & $\mathbf{1 1 . 1}$ & $\mathbf{2 0 . 4}$ & $\mathbf{0 . 3}$ \\
$\mathbf{2 . 4}$ & $\mathbf{2 3 . 3}$ & $\mathbf{2 9 . 5}$ & $\mathbf{1 2 . 0}$ & $\mathbf{1 0 . 9}$ & $\mathbf{2 4 . 2}$ & $\mathbf{0 . 3}$ \\
$\mathbf{2 . 8}$ & $\mathbf{8 . 8}$ & $\mathbf{2 5 . 2}$ & $\mathbf{2 6 . 7}$ & $\mathbf{1 8 . 1}$ & $\mathbf{2 1 . 3}$ & $\mathbf{0 . 3}$ \\
$\mathbf{3 . 0}$ & $\mathbf{1 4 . 9}$ & $\mathbf{2 3 . 8}$ & $\mathbf{1 5 . 8}$ & $\mathbf{1 2 . 4}$ & $\mathbf{3 3 . 2}$ & $\mathbf{0 . 5}$ \\
$\mathbf{3 . 2}$ & $\mathbf{2 . 4}$ & $\mathbf{1 2 . 0}$ & $\mathbf{1 7 . 9}$ & $\mathbf{2 0 . 8}$ & $\mathbf{4 6 . 9}$ & $\mathbf{0 . 8 8}$ \\
$\mathbf{3 . 4}$ & $\mathbf{1 3 . 2}$ & $\mathbf{2 8 . 7}$ & $\mathbf{1 4 . 2}$ & $\mathbf{1 6 . 5}$ & $\mathbf{2 7 . 4}$ & $\mathbf{0 . 4}$ \\
$\mathbf{3 . 4}$ & $\mathbf{1 1 . 6}$ & $\mathbf{5 0 . 7}$ & $\mathbf{1 6 . 4}$ & $\mathbf{7 . 2}$ & $\mathbf{1 4 . 2}$ & $\mathbf{0 . 2}$ \\
$\mathbf{3 . 5}$ & $\mathbf{5 . 2}$ & $\mathbf{1 9 . 5}$ & $\mathbf{1 4 . 6}$ & $\mathbf{2 0 . 5}$ & $\mathbf{4 0 . 2}$ & $\mathbf{0 . 7}$ \\
$\mathbf{3 . 6}$ & $\mathbf{0 . 0}$ & $\mathbf{2 1 . 1}$ & $\mathbf{1 6 . 4}$ & $\mathbf{2 2 . 9}$ & $\mathbf{3 9 . 7}$ & $\mathbf{0 . 7}$ \\
$\mathbf{3 . 7}$ & $\mathbf{4 . 7}$ & $\mathbf{3 8 . 3}$ & $\mathbf{1 6 . 1}$ & $\mathbf{1 5 . 7}$ & $\mathbf{2 5 . 3}$ & $\mathbf{0 . 3}$ \\
$\mathbf{3 . 8}$ & $\mathbf{9 . 1}$ & $\mathbf{5 5 . 6}$ & $\mathbf{1 2 . 7}$ & $\mathbf{6 . 8}$ & $\mathbf{1 5 . 8}$ & $\mathbf{0 . 2}$ \\
4.0 & 0.0 & 15.7 & 17.1 & 20.1 & 47.0 & 0.9 \\
4.1 & 0.0 & 11.1 & 22.6 & 16.4 & 49.9 & 1.0 \\
4.1 & 2.0 & 11.6 & 14.4 & 24.0 & 48.0 & 0.9 \\
5.1 & 0.0 & 2.7 & 8.7 & 14.0 & 74.6 & 2.9 \\
5.1 & 0.0 & 4.3 & 12.8 & 17.7 & 65.3 & 1.9 \\
5.5 & 0.0 & 8.8 & 11.3 & 14.2 & 65.7 & 1.9 \\
5.5 & 0.0 & 6.2 & 10.9 & 22.9 & 59.9 & 1.5 \\
\hline
\end{tabular}

(b) Core J20

\begin{tabular}{|c|c|c|c|c|c|c|}
\hline $\begin{array}{l}\text { Depth, } \\
\text { m }\end{array}$ & $>0.315$ & $\begin{array}{c}0.315- \\
0.1\end{array}$ & $\begin{array}{c}0.1- \\
0.063\end{array}$ & $\begin{array}{l}0.063- \\
0.036\end{array}$ & $<0.036$ & $\mathrm{~F}_{36}$ \\
\hline 1.48 & 0.00 & 8.82 & 5.88 & 20.59 & 60.78 & 1.7 \\
\hline 2.5 & 0.55 & 12.40 & 20.11 & 21.21 & 45.73 & 0.8 \\
\hline 3.00 & 2.37 & 24.93 & 16.32 & 16.32 & 38.87 & 06 \\
\hline 3.97 & 1.46 & 19.27 & 18.54 & 18.78 & 37.32 & 0.6 \\
\hline 4.49 & 1.36 & 14.74 & 17.01 & 17.01 & 43.54 & 0.87 \\
\hline 4.98 & 0.39 & 8.90 & 18.18 & 17.02 & 51.26 & 1.2 \\
\hline 5.50 & 0.21 & 11.39 & 15.53 & 16.77 & 56.11 & 1.3 \\
\hline 6.00 & 0.81 & 2.75 & 12.28 & 16.16 & 65.75 & 2.1 \\
\hline 6.98 & 0.49 & 2.10 & 4.45 & 12.36 & 72.31 & 3.7 \\
\hline 48 & 0.50 & 4.33 & 15.47 & 20.13 & 55.57 & 1.4 \\
\hline 7.98 & 2.41 & 7.67 & 15.34 & 22.87 & 47.73 & 1.0 \\
\hline 8.02 & 0.30 & 10.50 & 13.90 & 17.30 & 51.79 & 1.2 \\
\hline 8.36 & 4.47 & 29.48 & 13.86 & 11.83 & 36.08 & 0.6 \\
\hline 8.76 & 1.96 & 26.86 & 7.88 & 11.09 & 42.32 & 0.89 \\
\hline 8.90 & 2.52 & 22.66 & 16.32 & 11.24 & 44.17 & 0.8 \\
\hline 9.05 & 18.64 & 32.43 & 11.03 & 9.46 & 27.10 & 0.4 \\
\hline 9.25 & 11.70 & 28.72 & 11.21 & 10.36 & 36.33 & 0.6 \\
\hline 9.36 & 0.16 & 2.68 & 4.74 & 11.25 & 71.32 & 3.8 \\
\hline 9.47 & 0.24 & 3.17 & 6.68 & 13.58 & 74.61 & 3.2 \\
\hline 9.76 & 0.08 & 6.84 & 14.76 & 16.54 & 56.53 & 1.5 \\
\hline 10.30 & 0.33 & 2.25 & 4.61 & 6.70 & 85.00 & 6.1 \\
\hline 10.36 & 0.05 & 0.96 & 4.07 & 6.29 & 88.40 & 7.8 \\
\hline
\end{tabular}

(c) Core J31

\begin{tabular}{|c|c|c|c|c|c|c|}
\hline $\begin{array}{c}\text { Depth, } \\
\text { m }\end{array}$ & 0.315 & \begin{tabular}{|c|}
$0.315-$ \\
0.1 \\
\end{tabular} & \begin{tabular}{|c|}
$0.1-$ \\
0.063 \\
\end{tabular} & $\begin{array}{c}0.063- \\
0.036\end{array}$ & $<0.036$ & $\mathrm{~F}_{36}$ \\
\hline 0.45 & 0.00 & 9.09 & 9.17 & 13.14 & 68.84 & 2 \\
\hline 0.98 & & 6.20 & 5 & 21.20 & & 1.4 \\
\hline 1.16 & 1.73 & 20.86 & 9.45 & 10.68 & 44.38 & 1.0 \\
\hline 1.73 & 2.56 & 14.66 & 11.43 & 21.75 & 49.60 & 1.0 \\
\hline 2.16 & 2.58 & 3.74 & 3.05 & 8.17 & 64.81 & 3.7 \\
\hline 2.73 & & 9.09 & 10.30 & 20.00 & & 1.4 \\
\hline 3.00 & 1.47 & 2.59 & 5.19 & 12.78 & 69.96 & 3.2 \\
\hline 3.45 & & 9.86 & 10.14 & 6.08 & 68 & 2.2 \\
\hline & & 9.77 & 6.71 & 12.81 & & 2.4 \\
\hline 56 & 3.24 & 21.86 & 10.98 & 10.78 & & 1.2 \\
\hline 5.00 & 0.87 & 23.39 & 17.54 & 15.09 & 38.99 & 0.7 \\
\hline 5.25 & & 32.67 & 17.91 & 14.26 & 21.79 & 0.3 \\
\hline & 1 & 27.48 & 16.64 & 16.00 & 31.18 & 0.5 \\
\hline & 8 & 22.64 & 14.36 & 13.25 & & 1.0 \\
\hline 6.00 & & 7.72 & 5.45 & 9.37 & 69.43 & 2.9 \\
\hline 6.38 & 2.20 & 38.12 & 10.28 & 13.12 & 33.41 & 0.5 \\
\hline & & 31.76 & 15.57 & 13.16 & 32.50 & 0.5 \\
\hline & 5.79 & 41.34 & 9.41 & 6.20 & 33.60 & 0.5 \\
\hline & & 44.19 & 9.09 & 11.09 & 30.51 & 0.5 \\
\hline 73 & 12.21 & 43.66 & 14.33 & 12.64 & 16.81 & 0.2 \\
\hline & & 12.46 & 17.99 & 27.00 & 41.68 & 0.7 \\
\hline & & 4.96 & 15.64 & 24.61 & 52.78 & 1.2 \\
\hline & & 17.90 & 6.90 & 7.10 & 66.76 & 2.0 \\
\hline & 0.22 & 6.47 & 7.84 & 10.12 & 73.56 & 3.0 \\
\hline & 0.16 & 2.29 & 4.88 & 7.07 & 85.63 & 5.9 \\
\hline 9.05 & 0.40 & 1.12 & 3.39 & 9.11 & 85.47 & 6.1 \\
\hline
\end{tabular}

(d) Core J30

\begin{tabular}{c|r|r|r|r|r|l}
\hline $\begin{array}{c}\text { Depth, } \\
\mathrm{m}\end{array}$ & $\boldsymbol{>} 0.315$ & $\begin{array}{c}0.315 \\
0.1\end{array}$ & $\begin{array}{r}0.1- \\
0.063\end{array}$ & $\begin{array}{c}0.063 \\
0.036\end{array}$ & $<0.036$ & $\mathrm{~F}_{36}$ \\
\hline 0.70 & 2.78 & 16.65 & 13.98 & 10.43 & 44.66 & 1.0 \\
$\mathbf{0 . 8 8}$ & $\mathbf{1 4 . 1 0}$ & $\mathbf{1 4 . 6 4}$ & $\mathbf{6 . 4 7}$ & $\mathbf{1 3 . 2 9}$ & $\mathbf{3 7 . 6 0}$ & $\mathbf{0 . 8}$ \\
$\mathbf{1 . 0 5}$ & $\mathbf{4 . 0 6}$ & $\mathbf{1 7 . 9 8}$ & $\mathbf{1 2 . 7 8}$ & $\mathbf{1 5 . 3 1}$ & $\mathbf{4 4 . 5 8}$ & $\mathbf{0 . 8 9}$ \\
1.20 & 1.79 & 11.48 & 5.17 & 13.38 & 67.44 & 2.1 \\
$\mathbf{1 . 5 0}$ & $\mathbf{7 . 3 4}$ & $\mathbf{3 8 . 1 9}$ & $\mathbf{1 2 . 1 1}$ & $\mathbf{1 2 . 4 8}$ & $\mathbf{2 9 . 0 0}$ & $\mathbf{0 . 4}$ \\
2.35 & 2.90 & 6.66 & 10.64 & 16.50 & 63.04 & 1.7 \\
2.90 & 1.75 & 10.45 & 19.39 & 15.06 & 53.25 & 1.1 \\
$\mathbf{3 . 2 0}$ & $\mathbf{2 . 5 5}$ & $\mathbf{3 4 . 7 7}$ & $\mathbf{1 1 . 9 5}$ & $\mathbf{1 2 . 1 8}$ & $\mathbf{2 5 . 7 5}$ & $\mathbf{0 . 4}$ \\
3.35 & 1.56 & 21.10 & 11.06 & 13.25 & 52.71 & 1.1 \\
$\mathbf{3 . 4 0}$ & $\mathbf{1 8 . 4 1}$ & $\mathbf{3 9 . 8 0}$ & $\mathbf{1 4 . 0 6}$ & $\mathbf{7 . 3 8}$ & $\mathbf{1 5 . 3 8}$ & $\mathbf{0 . 2}$ \\
$\mathbf{3 . 4 8}$ & $\mathbf{1 9 . 2 0}$ & $\mathbf{2 9 . 7 7}$ & $\mathbf{9 . 3 9}$ & $\mathbf{7 . 2 1}$ & $\mathbf{3 1 . 0 3}$ & $\mathbf{0 . 5}$ \\
$\mathbf{3 . 5 8}$ & $\mathbf{2 5 . 7 0}$ & $\mathbf{3 6 . 4 0}$ & $\mathbf{1 3 . 6 7}$ & $\mathbf{6 . 4 4}$ & $\mathbf{1 6 . 3 0}$ & $\mathbf{0 . 2}$ \\
$\mathbf{3 . 6 6}$ & $\mathbf{1 6 . 8 6}$ & $\mathbf{3 2 . 2 6}$ & $\mathbf{1 7 . 6 5}$ & $\mathbf{1 0 . 9 4}$ & $\mathbf{1 8 . 3 6}$ & $\mathbf{0 . 2}$ \\
$\mathbf{3 . 8 0}$ & $\mathbf{2 9 . 5 7}$ & $\mathbf{3 9 . 3 5}$ & $\mathbf{1 1 . 1 9}$ & $\mathbf{6 . 4 5}$ & $\mathbf{1 3 . 7 1}$ & $\mathbf{0 . 2}$ \\
\hline
\end{tabular}




\section{DISCUSSION}

The distribution of grain size fractions depends on water depth at the sampling site (Table 1, Fig. 2). This clearly shows that with increasing water depth the average grain size spectrum of sediment shifts towards finer grains. Many researchers (Davis \& Ford 1982; Dearing 1997; Yang et al. 2002) have mentioned this relationship. As the topography of the lake basin is quite variable, the environmental conditions during sedimentation were determined by several morphometrical parameters. In L. Juusa it was possible to distinguish areas with greatly different grain size compositions of sediments. In shallower areas the content of coarse fractions is higher and the $\mathrm{F}_{36}$ values that could characterize the accumulation area vary from 0.2 to 0.9 . This area embraces the littoral up to a depth of ca $4.0 \mathrm{~m}$. The content of mineral matter in dry matter of surface sediments is mostly $>50 \%$ (Vaasma 2004). This area shows also notable variations in the proportions of the finest fraction, being indicative of the more complicated nature of the sedimentation processes.

The investigation of surface sediments of L. Juusa (LOI, grain size composition) by Terasmaa (2005) showed that, in addition to the water depth, the grain size composition of sediment is mainly determined by slope inclination and distance to the shore. On the basis of the results he developed a composite dimensionless parameter $(C P)$ that determines nearly half of the variation in the composition of the sediments. Analysis of spatial variation of the composite parameter showed that in case of L. Juusa (lake with a concave hypsographic curve) the accumulation area is characterized by $C P<2.3$ (confidence level 0.95 ) and the proportion of the sand fraction $(>0.063 \mathrm{~mm})$ is generally below $29 \%$. Analysis of grain size data of surface sediments (Fig. 2) shows that the $F_{36}$ values fit well with previous results and we can assume that the boundary between the erosion and transport area and the accumulation area (Håkanson 1977) lies approximately at a water depth of $4.0 \mathrm{~m}$. This estimation fits well with our previous data (Terasmaa 2004) and allow us to use the $F_{36}$ value $<0.9$ as a criterion for the accumulation area in L. Juusa in the past. As current analysis shows, there is a strong relationship between the $\mathrm{F}_{36}$ value and water depth at sampling points $(R=0.81, p<0.01)$.

Several cycles can be distinguished in the vertical distribution of grain size fractions in all core sections (Table 1, Fig. 2). The content of coarser and finer fractions in these cycles varies periodically, especially in deeper cores J31 and J20. In the basal part of all cores where the brownish gyttja contains several light interlayers, the grain size of the sediment differs markedly from the upper layer of different mud (gyttja) type. The basal layers of deep cores J20 and J31 (below 9.3 and $8 \mathrm{~m}$, respectively) show the domination of the silt and clay fractions $(<0.063 \mathrm{~mm})$, whereas at depths of $10 \mathrm{~m}$ in core J20 and 8.6 in core J31 the content of the $<0.036 \mathrm{~mm}$ fraction reaches over $80 \%$. In core J30, taken from the shallower area of the lake (Fig. 1), the sediments are underlain by coarser minerogenic matter.

Sharp increase in coarse material can be noticed in cores J20 and J31 at depths of 9.25 and $7.73 \mathrm{~m}$, respectively. Upwards (sediments at $8-9.25 \mathrm{~m}$ in core J20 

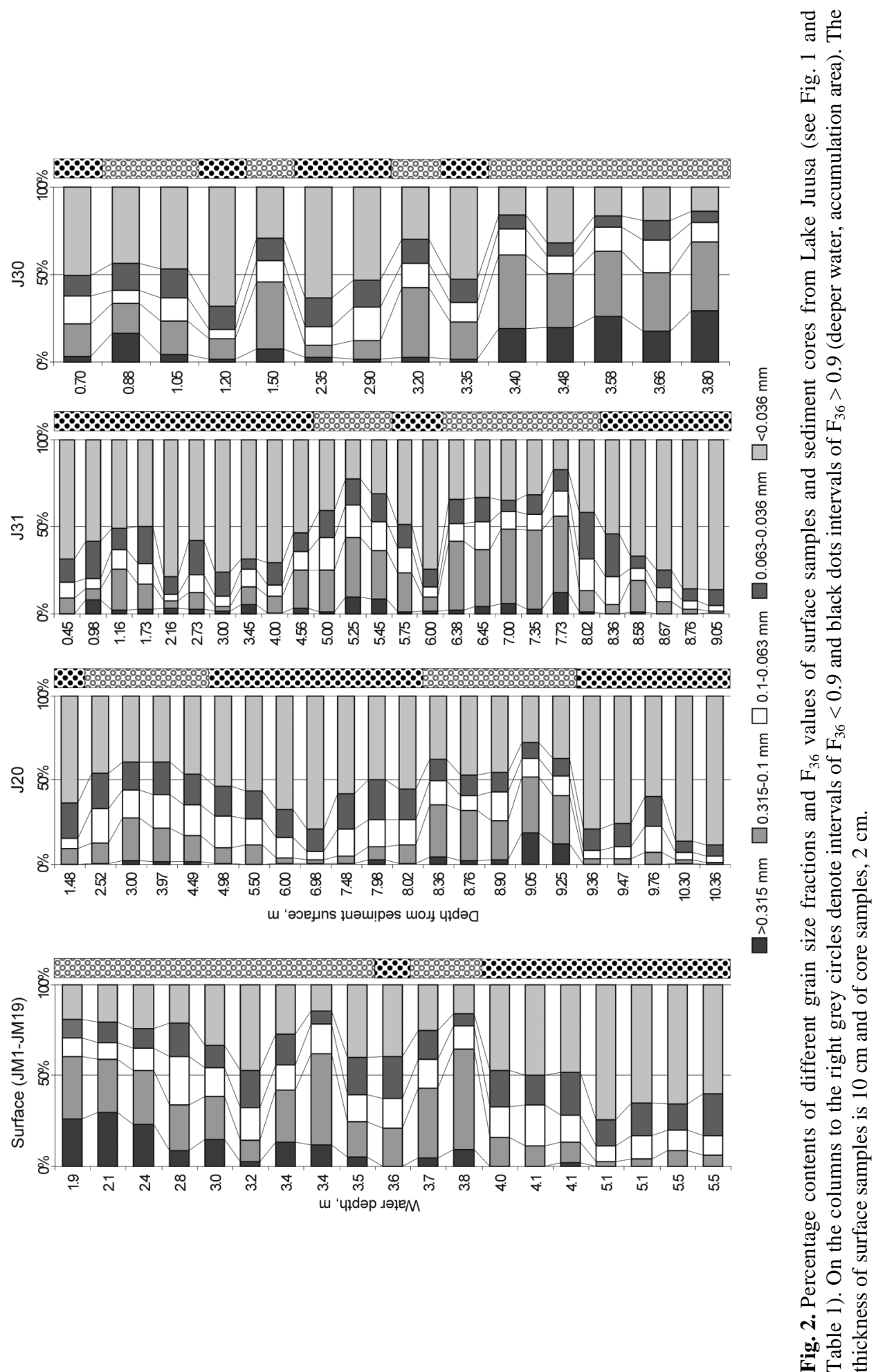
and 6-7.73 $\mathrm{m}$ in core J31), the content of the sand fraction (grain size mainly $0.1-$ $0.315 \mathrm{~mm}$ ) is also quite high. A thin layer overlying this complex (at $6.98 \mathrm{~m}$ in core J20 and at about $6 \mathrm{~m}$ in core J31) is considerably well sorted and consists of the finest fraction (up to 78\%). Blue Fe- and P-rich authigenic mineral inclusions formed of vivianite were also determined in this level. Higher above this wellsorted layer the content of sand fractions $(>0.315$ and $0.1-0.315 \mathrm{~mm})$ grows again until to depths of about 3-4 $\mathrm{m}$ in core $\mathrm{J} 20$ and $4-5 \mathrm{~m}$ in core $\mathrm{J} 31$.

According to the variation in $\mathrm{F}_{36}$ it is possible to define certain depth intervals in all cores. Two intervals of cores J20 and J31 display higher values of $F_{36}$ (Fig. 2, Table 1), showing the prevalence of finer particles. In core J30 only the lower layers have elevated values of $F_{36}$, while in the upper layers variations are rather occasional due to unstable accumulation conditions.

Assuming that the $\mathrm{F}_{36}$ values characterize the sedimentation area, it is possible to estimate the intervals when the coring sites are situated within the accumulation areas. Those periods are marked with a black dotted pattern in Fig. 2. Based on the results obtained, we can reconstruct the history of the lake in the past, including the individual sedimentation zones and amplitude of single lake-level fluctuations. This facilitates understanding the functioning of the ecosystem during different hydrothermic regimes, which is necessary for palaeolimnological studies and modelling of the processes in the future.

\section{CONCLUSIONS}

Grain size distribution in the sediment core is a valuable indicator of waterlevel fluctuations in the past. Analysis of the grain size pattern of surface samples taken from L. Juusa revealed the relationships between water depth and grain size. The extension of these relationships to the core data showed essential changes in the hydrological regime of the lake during the Holocene.

The ratio of the smallest fraction $(<0.036 \mathrm{~mm})$ to the sum of coarser fractions found for surface samples serves as a good basis for generalizing data and differentiating samples from areas with different sedimentation conditions. With the help of this ratio $\left(\mathrm{F}_{36}\right)$ depth intervals could be distinguished, indicating periods with a higher water level and more stable accumulation conditions in all cores. A similar grain size composition of surface samples is recorded only in certain areas where water depth is over $4 \mathrm{~m}$.

\section{ACKNOWLEDGEMENTS}

We express our sincere thanks to M. Kangur and T. Koff for participating in fieldwork and discussions. Financial support from the Estonian Ministry of Education (project No. 0282120s02) and Estonian Science Foundation (grant No. 5584) is gratefully acknowledged. 


\section{REFERENCES}

Aaby, B. \& Berglund, E. B. 1986. Characterization of peat and lake deposits. In Handbook of Holocene Palaeoecology and Palaeohydrology (Berglund, E. B., ed.), pp. 231-246. John Wiley \& Sons, Chichester.

Beierle, B. D., Lamoreux, S. F., Cockburn, M. H. \& Spooner, I. 2002. A new method for visualizing sediment particle size distribution. J. Paleolimnol., 27, 279-283.

Bengtsson, L. \& Enell, M. 1986. Chemical analysis. In Handbook of Holocene Palaeoecology and Palaeohydrology (Berglund, B. E., ed.), pp. 423-451. John Wiley \& Sons, Chichester.

Blais, J. M. \& Klaff, J. 1995. The influence of lake morphometry on sediment focusing. Limnol. Oceanogr., 40, 582-588.

Boyle, J. F. 2001. Inorganic geochemical methods in palaeolimnology. In Tracking Environmental Change Using Lake Sediments, Volume 2 - Physical and Geochemical Methods (Last, W. M. \& Smol, J. P., eds.), pp. 83-141. Kluwer Academic Publishers, London.

Davis, M. B. \& Ford, M. S. 1982. Sediment focusing in Mirror Lake, New Hampshire. Limnol. Oceanogr., 27, 137-156.

Dearing, J. A. 1983. Changing pattern of sediment accumulation in a small lake in Scania, southern Sweden. Hydrobiologia, 103, 59-64.

Dearing, J. A. 1997. Sedimentary indicators of lake-level changes in the humid temperate zone: a critical review. J. Paleolimnol., 18, 1-14.

Digerfeldt, G. 1986. Studies on past lake-level fluctuations. In Handbook of Holocene Palaeoecology and Palaeohydrology (Berglund, B. E., ed.), pp. 127-143. John Wiley and Sons, Chichester.

Engstrom, D. R., Swain, E. B. \& Kingston, J. C. 1985. A paleolimnological record of human disturbance from Harvey's Lake, Vermont: geochemistry, pigments and diatoms. Freshwater Biol., 15, 261-288.

Folk, R. L. 1980. Petrology of Sedimentary Rocks. Hemphill Publishing Company, Austin, Texas.

Håkanson, L. 1977. The influence of wind, fetch and water depth on the distribution of sediments in Lake Vänern, Sweden. Canadian J. Earth Sci., 14, 397-412.

Håkanson, L. \& Jansson, M. 1983. Principles of Lake Sedimentology. Springer-Verlag, Berlin.

Last, W. M. 2001. Mineralogical analysis of lake sediments. In Tracking Environmental Change Using Lake Sediments, Volume 2 - Physical and Geochemical Methods (Last, W. M. \& Smol, J. P., eds.), pp. 143-187. Kluwer Academic Publishers, London.

Marchetto, A., Lami, A., Musazzi, S., Massaferro, J., Langone, L. \& Gullizzoni, P. 2004. Lake Maggiore (N. Italy) trophic history: fossil diatom, plant pigments, and chironomids, and comparison with long-term limnological data. Quat. Intern., 11, 97-110.

Punning, J.-M. \& Leeben, A. 2003. A comparison of sediment and monitoring data: implications for paleomonitoring a small lake. Environ. Monitoring Assessment, 64, 549-567.

Punning, J.-M. K., Raukas, A. V., Serebryannyj, L. R. \& Stelle, V. Ya. 1968. Paleogeographic peculiarities and absolute age of the Luga stadial of the Valdai glaciation on the Russian Plain. Dokl. Akad. Nauk SSSR Geol., 178, 916-918 (in Russian).

Punning, J.-M., Puusepp, L. \& Koff, T. 2004a. Spatial variability of diatoms, subfossil macrophytes, and $\mathrm{OC} / \mathrm{N}$ values in surface sediments of Lake Väike Juusa (southern Estonia). Proc. Estonian Acad. Sci. Biol. Ecol., 53, 147-160.

Punning, J.-M., Alliksaar, T., Terasmaa, J. \& Jevrejeva, S. 2004b. Recent patterns of sediment accumulation in a small closed eutrophic lake revealed by the sediment records. Hydrobiologia, 529, 71-81.

Punning, J.-M., Koff, T., Kadastik, E. \& Mikomägi, A. 2005. Holocene lake level fluctuations recorded in the sediment composition of Lake Juusa, SE Estonia. J. Paleolimnol. (submitted).

Raukas, A. 1999. Lithology: grain size. In Lake Peipsi. Geology (Miidel, A. \& Raukas, A., eds.), pp. 67-72. Sulemees Publishers, Tallinn. 
Shteinman, B. S. \& Parparov, A. S. 1997. An approach to particulate matter transfer studies in littoral zones of lakes with changing morphometry. Water Sci. Technol., 36, 199-205.

Terasmaa, J. 2004. Settimisrežiimi määravad tegurid ja nende analüüs kahes Eesti väikejärves. In Geoökoloogilisi uurimusi, Vol. 8 (Kadastik, E. \& Punning, J.-M., eds.), pp. 36-60. Institute of Ecology Publications, Tallinn.

Terasmaa, J. 2005. Bottom topography and sediment lithology in two small lakes in Estonia. Proc. Estonian Acad. Sci. Biol. Ecol. (accepted).

Troels-Smith, J. 1955. Characterisation of unconsolidated sediments. Danm. geol. Unders. Ser. IV, 3(10).

Vaasma, T. 2004. Väike Juusa järve ja Viitna Linajärve nüüdissetete litoloogiline ja granulomeetriline koostis. Bachelor's thesis, Tallinn Pedagogical University.

Yang, H., Rose, N. L., Battarbee, R. W. \& Monteith, D. 2002. Trace metal distribution in the sediments of the whole lake basin for Lochnagar, Scotland: a palaeolimnological assessment. Hydrobiologia, 479, 51-61.

\title{
Väike Juusa järve põhjasetete terasuuruse muutuste seos veetaseme kõikumistega
}

\author{
Jaan-Mati Punning, Jaanus Terasmaa ja Ene Kadastik
}

On analüüsitud Otepää kõrgustikul paikneva Väike Juusa järve 19 pindmise setteproovi ja põhjasetetest võetud 3 puursüdamiku 62 proovi granulomeetrilist koostist. On leitud, et pindmistes setetes suureneb peenterisemate fraktsioonide osakaal proportsionaalselt veesügavuse suurenemisega. Akumulatsioonialas, mis Väike Juusa järves asub sügavamal kui $4 \mathrm{~m}$, on $<0,036 \mathrm{~mm}$ terasuurusega fraktsiooni sisalduse suhe jämeterisesse settesse $<0,9$.

Litoloogilise koostise ja terasuuruse variatsioonid puursüdamikest võetud proovides on suuresti tingitud järve minevikus aset leidnud veetaseme kõikumistest. Kasutades pindmiste setete analüüsil saadud seoseid terasuuruse ja settimissügavuse vahel, on võimalik rekonstrueerida veetaseme kõikumiste amplituud kogu Holotseeni kohta. 